\title{
Relief of G-Protein Inhibition of Calcium Channels and Short-Term Synaptic Facilitation in Cultured Hippocampal Neurons
}

\author{
David L. Brody and David T. Yue \\ The Johns Hopkins University School of Medicine, Departments of Biomedical Engineering and Neuroscience, Program \\ in Molecular and Cellular Systems Physiology, Baltimore, Maryland 21205
}

G-protein inhibition of voltage-gated calcium channels can be transiently relieved by repetitive physiological stimuli. Here, we provide evidence that such relief of inhibition contributes to short-term synaptic plasticity in microisland-cultured hippocampal neurons. With G-protein inhibition induced by the $\mathrm{GABA}_{\mathrm{B}}$ receptor agonist baclofen or the adenosine $\mathrm{A} 1$ receptor agonist 2-chloroadenosine, short-term synaptic facilitation emerged during action potential trains. The facilitation decayed with a time constant of $\sim 100 \mathrm{msec}$. However, addition of the calcium channel inhibitor $\mathrm{Cd}^{2+}$ at 2-3 $\mu \mathrm{m}$ had no such effect and did not alter baseline synaptic depression. As expected of facilitation from relief of channel inhibition, analysis of miniature EPSCs implicated presynaptic modulation, and elevating presynaptic $\mathrm{Ca}^{2+}$ entry blunted the facilitation. Most telling was the near occlusion of synaptic facilitation after selective blockade of $P / Q$ - but not N-type calcium channels. This was as predicted from experiments using recombinant calcium chan- nels expressed in human embryonic kidney (HEK) 293 cells; we found significantly stronger relief of G-protein inhibition in recombinant $P / Q$ - versus $\mathrm{N}$-type channels during action potential trains. G-protein inhibition in HEK 293 cells was induced via recombinant $\mathrm{M} 2$ muscarinic acetylcholine receptors activated by carbachol, an acetylcholine analog. Thus, relief of G-protein inhibition appears to produce a novel form of short-term synaptic facilitation in cultured neurons. Similar short-term synaptic plasticity may be present at a wide variety of synapses, as it could occur during autoreceptor inhibition by glutamate or GABA, heterosynaptic inhibition by GABA, tonic adenosine inhibition, and in many other instances.

Key words: short-term synaptic plasticity; facilitation; GABA; baclofen; G-protein inhibition; calcium channels; recombinant calcium channels; microcultures; cultured neurons; autapses; hippocampal neurons; adenosine; HEK 293 cells
Short-term synaptic plasticity may dramatically affect neuronal information transfer (Magleby, 1987; Zucker, 1989; Markram and Tsodyks, 1996; Sejnowski, 1996; Abbott et al., 1997; Tsodyks and Markram, 1997; Dobrunz and Stevens, 1999). Because neurotransmitter release depends supralinearly on presynaptic calcium entry through voltage-gated calcium channels, spike-to-spike changes in calcium currents could contribute substantially to synaptic plasticity. There has to date, however, been little evidence of this class of mechanisms (Borst and Sakmann, 1998; Cuttle et al., 1998; Forsythe et al., 1998). In particular, presynaptic calcium currents in well studied invertebrate neurons appear invariant from stimulus to stimulus (Smith and Zucker, 1980; Charlton et al., 1982; Wright et al., 1996). However, studies of vertebrate preparations provide growing evidence that during repetitive physiological stimuli, calcium channels may manifest progressive increases in current because of relief of G-proteinmediated inhibition. Specifically, in somatic and recombinant channels G-protein-mediated inhibition can be transiently re-

Received Aug. 16, 1999; revised Nov. 8, 1999; accepted Nov. 9, 1999.

This work was supported by National Institutes of Health and National Science Foundation grants to D.T.Y. and a Medical Scientist Training Program fellowship to D.L.B. We thank C. Boyer and C. F. Stevens for the microisland culture protocol; A. Ghosh, C. Jahr, and C. Zorumski for initial advice on neuronal cell culture; SIBIA Neuroscience (human $\alpha_{1 \mathrm{~B}}$ ), T. Snutch, E. Perez-Reyes, and E. Peralta for clones; K. Elmslie for the generous gift of the $\omega$ Aga-IVA; and C. Aizenmann, H. Colecraft, D. DiGregorio, J. Dittmann, L. Jones, D. Linden, and P. Fuchs for helpful discussions and comments on this manuscript.

Correspondence should be addressed to Dr. David T. Yue, The Johns Hopkins University School of Medicine, Department of Biomedical Engineering, Program in Molecular and Cellular Physiology, 720 Rutland Avenue, Baltimore, MD 21205. E-mail: dyue@bme.jhu.edu.

Copyright (C) 2000 Society for Neuroscience $0270-6474 / 00 / 200889-10 \$ 15.00 / 0$ lieved by trains of voltage-clamp action potentials and strong depolarizations (Bean, 1989; Elmslie et al., 1990; Brody et al., 1997; Williams et al., 1997; Park and Dunlap, 1998; Tosetti et al., 1999), although there can be a tonic component of inhibition that is insensitive to depolarization in some preparations (Shapiro and Hille, 1993; Luebke and Dunlap, 1994). Such activitydependent reversal of calcium channel inhibition could occur in presynaptic calcium channels as well, since at least the initial inhibition of neuronal calcium channels by G-proteins is known to underlie the suppression of neurotransmitter release produced when a wide variety of G-protein-coupled receptors are activated (Toth et al., 1993; Wu and Saggau, 1994, 1995; Dittman and Regehr, 1996; Takahashi et al., 1996). Although several groups have noted that this relief of inhibition potentially could cause a form of short-term synaptic facilitation (Elmslie et al., 1990; Shen and Horn, 1996; Brody et al., 1997), no explicit investigations of this proposal have been performed in synaptic preparations. Here, we tested for such a facilitation in single, cultured rat hippocampal neurons. When grown on glial microislands, the neurons form extensive synaptic connections onto themselves ("autapses") (Van der Loos and Glaser, 1972), which have properties very similar to those of synapses between neurons (Bekkers and Stevens, 1991; Johnson and Yee, 1995; Goda and Stevens, 1996). Such autapses show large postsynaptic responses and thereby provide a convenient system for studying short-term plasticity, especially under conditions in which neurotransmission is reduced such as during G-protein-mediated inhibition and presynaptic calcium channel blockade.

It has been widely observed that short-term synaptic depression 
Figure 1. Short-term synaptic plasticity was changed during calcium channel inhibition by G-proteins but not by $\mathrm{Cd}^{2+}$. $A$, EPSCs measured in microisland cultures of hippocampal neurons. After a somatic voltage-clamp stimulus (stim.; top), voltage-gated and capacitive currents were followed by inward synaptic currents $(a)$. Responses in $2 \mu \mathrm{M}$ NBQX $(n)$ were subtracted from total currents $(a)$ to isolate synaptic currents $(a-n)$, which were integrated over a 2-20 msec window after the stimulus ( $\left.Q_{\text {EPSC }}\right)$. $B$, Diary plot of $Q_{\mathrm{EPSC}}$ for the first (solid diamonds) and second (open squares) stimuli of 50 $\mathrm{Hz}$ stimulus trains. $\mathrm{Cd}^{2+}$ concentration was titrated so that the initial EPSC amplitude was similar to that during G-protein-mediated inhibition induced by $10 \mu \mathrm{M}$ baclofen. $C$, Isolated synaptic currents during $50 \mathrm{~Hz}$ trains showing short-term plasticity at baseline (control; left), during G-protein-mediated inhibition (baclofen; middle), and in $\mathrm{Cd}^{2+}$ (right). D, Normalized $Q_{\text {EPSC }}$ averages across 12 cells. In all cells included in the average, $\mathrm{Cd}^{2+}$ blockade was titrated to match the extent of baclofen inhibition. Left, Normalization by the first $Q_{\text {EPSC }}$ in control (solid squares) for each cell. Baclofen (open circles) inhibited the first $Q_{\text {EPSC }}$ by $75 \pm 4 \%$, and $\mathrm{Cd}^{2+}$ ( gray triangles; typically $2-3 \mu \mathrm{M}$ ) inhibited by $71 \pm 4 \%$. Right, Normalization by the first $Q_{\text {EPSC }}$ in each condition to facilitate comparison of short-term synaptic plasticity. Plasticity was significantly different between baclofen and control and between baclofen and $\mathrm{Cd}^{2+}$ for the second and all subsequent responses $(p<0.005)$ but was not different between $\mathrm{Cd}^{2+}$ and control $(p>0.27)$.
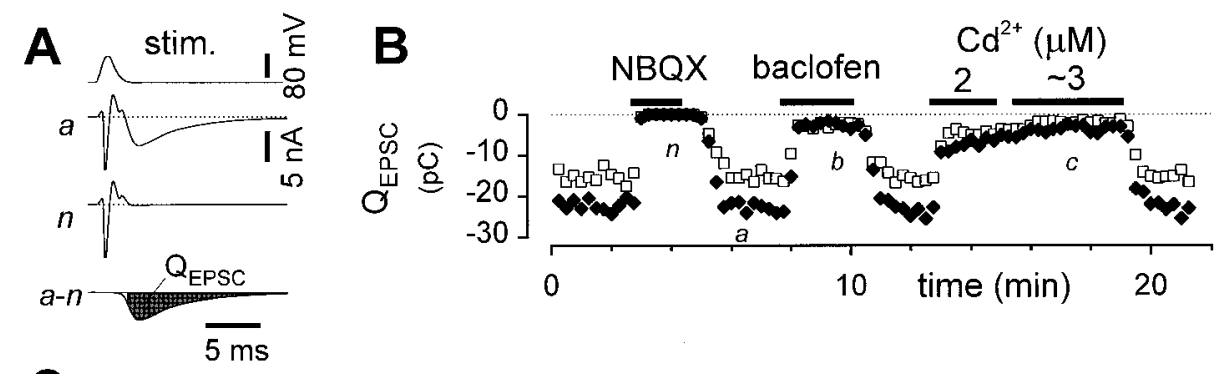

C $a-n \longrightarrow$ control

$b-n \multimap-$ baclofen
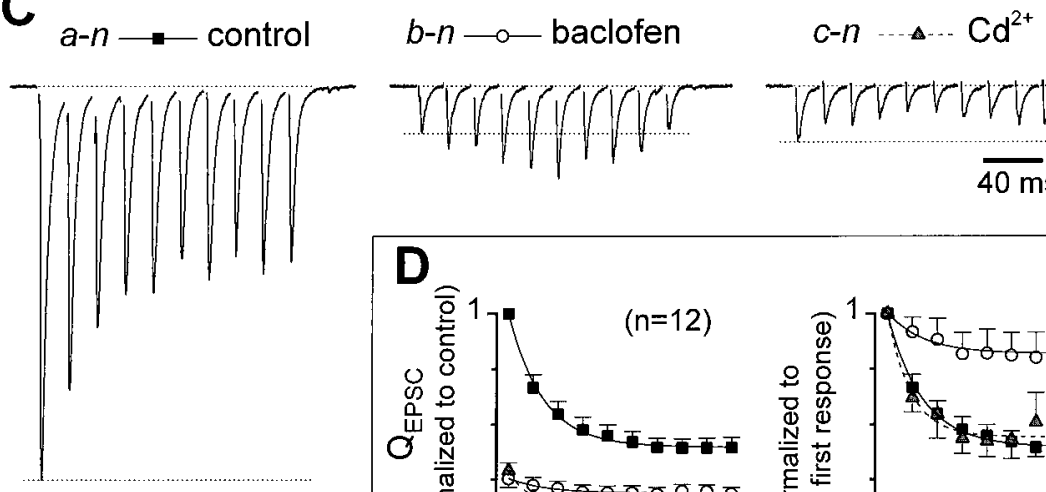
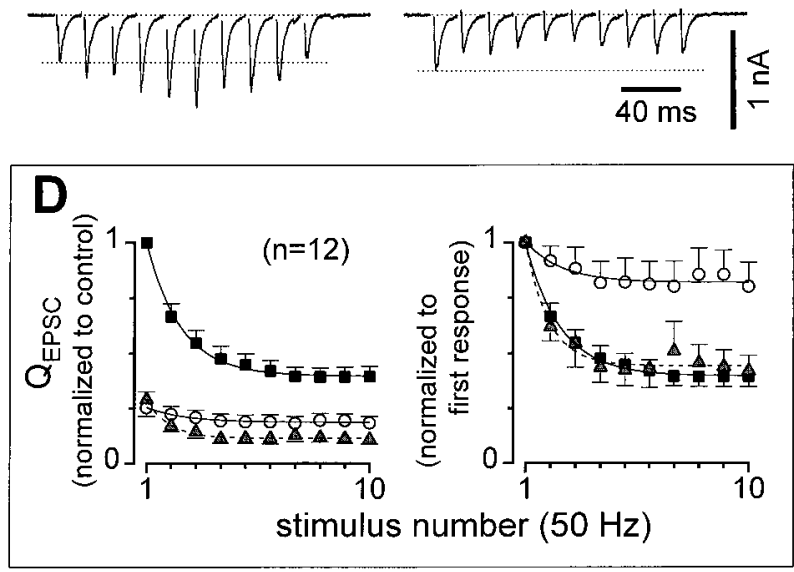

(STD) is attenuated by an overall reduction of neurotransmitter release (Lev-Tov and Pinco, 1992; Barnes-Davies and Forsythe, 1995; Isaacson and Hille, 1997; Varela et al., 1997; Brenowitz et al., 1998) such as during G-protein-mediated inhibition. These effects on synaptic efficacy have been attributed to releasedependent mechanisms such as vesicle depletion (Zucker, 1989). By contrast, we have found that G-protein-mediated inhibition reduces STD or converts it to relative facilitation, in a manner that appears distinct from release-dependent mechanisms but consistent with relief of G-protein-mediated inhibition of calcium channels.

\section{MATERIALS AND METHODS}

Cell culture. Hippocampal neurons were cultured on glial microislands essentially as reported (Furshpan et al., 1986; Bekkers and Stevens, 1991). Briefly, a $0.15 \%$ agarose solution was spread uniformly on glass coverslips; then $2 \mathrm{mg} / \mathrm{ml}$ poly-D-lysine plus $3 \mathrm{mg} / \mathrm{ml}$ collagen (Cellprime; Collagen Corporation, Palo Alto, CA) in $8.5 \mathrm{~mm}$ acetic acid was airbrush (Aztek, Rockford, IL) spattered to form 50- to 750- $\mu$ m-diameter "islands" of adhesive substrate. Cultured rat astrocytes were plated at a density of 6,000-24,000 cells/ml in Minimal Essential Medium (MEM) with Earle's salts (Life Technologies, Gaithersburg, MD), 10\% fetal calf serum, $20 \mathrm{~mm}$ glucose, $0.5 \% \mathrm{~N} 2$ supplement (Life Technologies), $0.5 \%$ penicillin/streptomycin stock, and phenol red. After $4-6 \mathrm{~d}$ at $37^{\circ} \mathrm{C}$ in a $5 \% \mathrm{CO}_{2}$ atmosphere, the astrocytes spread out over the microislands but did not grow on the agarose. Neurons were isolated by trituration of papain-digested, CA1- and CA3-enriched hippocampi from 1- to 2-d-old Sprague Dawley rats. Between 2,000 and 28,000 cells/ml were added to the plates containing astrocytes, and they were cultured in MEM with Earle's salts plus $25 \mathrm{~mm}$ HEPES (Life Technologies), 10\% horse serum (Life Technologies), $20 \mathrm{~mm}$ glucose, $1 \% \mathrm{~N} 2$ supplement, $1 \mathrm{~mm}$ sodium pyruvate, $0.5 \%$ penicillin/streptomycin stock, and $0.875 \mathrm{mg} / \mathrm{ml}$ biotin. The day after plating, $35 \mu \mathrm{M}$ 5-fluoro-2-deoxyuridine (Sigma, St. Louis, $\mathrm{MO})$ with $75 \mu \mathrm{M}$ uridine was added. The culture medium was not changed for up to $21 \mathrm{~d}$ in vitro.
Electrophysiology. Recordings were made after 7-21 d in vitro. Wholecell patch-clamp pipets with a resistance of 3-4 $\mathrm{M} \Omega$ were pulled from borosilicate glass and filled with (in mM): 137 Kgluconate, $12 \mathrm{NaCl}, 10$ HEPES, 4 EGTA, $0.5 \mathrm{CaCl}_{2}, 4 \mathrm{MgATP}$, and $0.3 \mathrm{LiGTP}$, pH 7.2 with $\mathrm{KOH}$. The standard extracellular solution contained (in mM): $145 \mathrm{NaCl}$, $5.4 \mathrm{KCl}, 2 \mathrm{CaCl}_{2}, 1 \mathrm{MgCl}_{2}$, and $10 \mathrm{HEPES}, \mathrm{pH} 7.4$ with $\mathrm{NaOH}$, adjusted to $310 \mathrm{mOsm}$ with $15-25 \mathrm{~mm}$ glucose. For early experiments, the intracellular solution contained 145 Kgluconate and $4 \mathrm{NaCl}$ but was otherwise unchanged. No differences were apparent because of these changes, and results have been pooled. All chemicals were from Sigma except for baclofen, 2-chloroadenosine (2-CADO), and 1,2,3,4-tetrahydro-6-nitro2,3-dioxo-benzo(f)quinoxaline-7-sulfonamide (NBQX) from Research Biochemicals (Natick, MA), $\omega$ Ctx-GVIA from Alomone Labs (Jerusalem, Israel), and $\omega$ Aga-IVA (a gift from Dr. K. Elmslie, Tulane University). A $-14 \mathrm{mV}$ junction potential (pipet minus bath) was corrected before sealing. All recordings were made at room temperature (23$25^{\circ} \mathrm{C}$ ). Filtering was at $5 \mathrm{kHz}$, sampling was at $25 \mathrm{kHz}$, and the holding potential was $-80 \mathrm{mV}$. Series resistance was typically 6-10 $\mathrm{M} \Omega$ and compensated $50-85 \%$ when possible. EPSCs stabilized in 3-5 min after break-in, and data traces were acquired every 15-30 sec. EPSC integrals followed the same trends as peak EPSCs but showed less variability from sweep to sweep and were more sensitive to the contribution of slightly asynchronous release events (data not shown). EPSC records have been displayed after subtraction of NBQX-insensitive currents (Fig. $1 A$ ), and $1-3$ msec around each stimulus has been blanked for clarity. NBQXinsensitive currents were unchanged in baclofen, 2-CADO, or 2-3 $\mu \mathrm{M}$ $\mathrm{Cd}^{2+}$ (data not shown). Rundown or decreases in EPSC amplitude over tens of minutes occurred in some cells but did not significantly affect short-term synaptic plasticity (data not shown). When EPSC amplitudes in two conditions were compared, measurements were bracketed or made within 5-10 min of each other. Minis were recorded without series resistance compensation and were bandpass filtered between 10 and 1000 $\mathrm{Hz}$; 500-800 sweeps of minis were obtained per cell. Mini amplitudes were measured in a semiautomatic manner using custom software in Matlab and confirmed by visual inspection. $\mathrm{Cd}^{2+}(2 \mu \mathrm{M})$ had no effect on minis; their amplitudes were clearly altered by changing the baseline potential, and NBQX eliminated them entirely (data not shown). In 4 
$\mathrm{mM} \mathrm{Ca}^{2+}$ plus $100 \mu \mathrm{M}$ 4-aminopyridine (4-AP) experiments, extracellular $\mathrm{Mg}^{2+}$ was removed, extracellular NBQX was used at $5 \mu \mathrm{M}$, and intracellular $\mathrm{Na}^{+}$was $4 \mathrm{~mm}$. For toxin experiments, $1 \mathrm{mg} / \mathrm{ml}$ bovine serum albumin and $0.1 \mathrm{mg} / \mathrm{ml}$ cytochrome $\mathrm{C}$ were added to the bath. $\omega \mathrm{Ctx}$-GVIA rapidly and irreversibly reduced initial EPSCs, but $\omega$ AgaIVA's effects reversed partially over tens of minutes, so all measurements were obtained within a few minutes of toxin application.

Transfection of human embryonic kidney 293 cells. Human embryonic kidney (HEK) 293 cells were transiently transfected using calcium phosphate precipitation with the following calcium channel clone cDNAs: rat brain $\alpha_{1 \mathrm{~A}}$ (Starr et al., 1991) or human brain $\alpha_{1 \mathrm{~B}}$ (Williams et al., 1992) plus $\alpha_{2} \delta$ (Tomlinson et al., 1993) and one of three $\beta$ subunits: $\beta_{2 a}$ (Perez-Reyes et al., 1992), $\beta_{3}$ (Castellano et al., 1993a), or $\beta_{4}$ (Castellano et al., 1993b). M2 receptor cDNA (Peralta et al., 1987) was included as well. Methods were otherwise as described (Brody et al., 1997).

Statistical analysis. All $p$ values for pairwise comparisons represent two-tailed, paired $t$ test results or two-tailed, unequal variance $t$ test results as appropriate; $p>0.05$ was considered not significant. Error values $( \pm)$ were SEs. Approximate confidence intervals for fit parameters were calculated using the "locally linear hypothesis" (Pandit and $\mathrm{Wu}$, 1990). $t$ tests between pairs of fit parameters were performed using approximate SDs calculated in the same manner.

\section{RESULTS}

\section{Changes in short-term synaptic plasticity after activation of G-protein-coupled receptors}

To record postsynaptic currents, we delivered brief voltage-clamp stimuli via a somatic, whole-cell patch pipet (Fig. $1 \mathrm{~A}$, top). A propagating action potential was generated, with momentary loss of voltage-clamp control because of large sodium and potassium currents corresponding to initial inward and outward currents, respectively. Subsequently, inward current flowed through AMPA-type glutamate receptors (Fig. $1 A, a$ ) that were recorded with good voltage-clamp control. Subtraction of responses obtained with the AMPA-antagonist NBQX (Fig. 1 $A, n$ ) isolated synaptic currents (Fig. $1 A, a-n)$, which were integrated to quantitate EPSCs (Fig. $1 A, Q_{\text {EPSC }}$ ). Evidence of good voltage-clamp control during EPSCs included an extrapolated EPSC reversal potential near $0 \mathrm{mV}$ and unchanged short-term synaptic depression when the sizes of the EPSCs were reduced using subsaturating concentrations of NBQX (data not shown) (Bekkers and Stevens, 1991).

We tested for changes in short-term synaptic plasticity attributable to relief of G-protein-mediated inhibition by comparing synaptic responses in the absence and presence of G-proteincoupled receptor agonists. In control conditions, autapses showed STD in response to $50 \mathrm{~Hz}$ trains of stimuli, as illustrated by the decrement of $Q_{\text {EPSC }}$ between the first and second responses (Fig. $1 B$ ) and exemplar records (Fig. $1 C$, left). Population data uniformly confirmed such baseline depression (Fig. 1D, solid squares). By contrast, the pattern of short-term synaptic plasticity was qualitatively different after application of the $\mathrm{GABA}_{\mathrm{B}}$ agonist baclofen $(10 \mu \mathrm{M})$. Initial EPSCs were inhibited by $75 \pm 4 \%$, and the depression converted to relative facilitation (Fig. $1 C$, middle) or appeared markedly reduced (Fig. $1 D$, open circles), as would be predicted for relief of G-protein-mediated inhibition of presynaptic calcium channels. These effects were not unique to inhibition via $\mathrm{GABA}_{\mathrm{B}}$ receptors, because nearly identical inhibition and changes in short-term plasticity were seen with $1 \mu \mathrm{M}$ 2-CADO, which also activates G-proteins via adenosine A1 receptors (data not shown).

\section{Alternative hypotheses to relief of G-protein-mediated inhibition of calcium channels}

In addition to the possibility of dynamic changes in $\mathrm{Ca}^{2+}$ influx through calcium channels, a number of more traditional explana- tions could account for the effects of baclofen on synaptic plasticity. The most prominent among these involves releasedependent short-term depression mechanisms such as vesicle depletion, postsynaptic receptor desensitization, and autoreceptor inhibition by glutamate (Zucker, 1989), which may underlie short-term depression in many synapses. For example, if vesicle depletion were occurring, the baclofen-induced reduction in overall presynaptic $\mathrm{Ca}^{2+}$ influx through calcium channels would decrease fractional depletion of releasable vesicles per action potential, thereby diminishing short-term synaptic depression. To exclude this possibility, we titrated the calcium channel blocker $\mathrm{Cd}^{2+}$ into the bath to mimic the initial reduction of release probability produced by baclofen (Fig. $1 B$ ). Like G-proteinmediated inhibition, $\mathrm{Cd}^{2+}$ in effect reduces channel open probability. Unlike G-protein-mediated inhibition, however, $\mathrm{Cd}^{2+}$ blockade appears to be voltage independent over a physiological voltage range (Leonard et al., 1987) and remains invariant with repetitive stimulation of calcium channels (see Discussion). Despite a substantial reduction in transmitter release by $\mathrm{Cd}^{2+}$, the short-term synaptic depression was unaffected in almost all cells (Fig. $1 C$, right, D, gray triangles). In rare recordings (3 of 29), there was somewhat less depression in $\mathrm{Cd}^{2+}$. However, baclofen or 2-CADO always produced even greater changes in short-term plasticity than did $\mathrm{Cd}^{2+}$ (data not shown). These results excluded a contribution of release-dependent mechanisms to the changes in synaptic plasticity produced by baclofen. Instead, our unpublished results suggest that baseline depression in this preparation may reflect action potential propagation failure at axonal branch points (Parnas, 1972; Hatt and Smith, 1976; Macagno et al., 1987; Streit et al., 1992; Wall, 1995; Debanne et al., 1997).

A remaining conventional explanation for the baclofeninduced changes in plasticity was that facilitation caused by residual calcium bound to presynaptic effectors was potentiated with lowered calcium entry (Rahamimoff, 1968; Stanley, 1986). This possibility seemed unlikely because our pipet solution contained a high concentration of EGTA, which would chelate residual $\mathrm{Ca}^{2+}$ (Hochner et al., 1991; Atluri and Regehr, 1996). It appeared that this EGTA effectively diffused to the presynaptic terminals, because after whole-cell access was obtained, the rate of spontaneous miniature EPSCs was initially high but declined over 3-5 min. Furthermore, bath-applied EGTA AM had no effect on short-term synaptic plasticity (data not shown). Most importantly, facilitation from residual calcium was ruled out by the invariance of short-term synaptic plasticity with the addition of $\mathrm{Cd}^{2+}$ (Fig. 1D).

Having excluded major known forms of synaptic plasticity that could have produced our results, we next considered novel mechanisms other than relief of G-protein-mediated inhibition. One possibility was that baclofen and 2-CADO attenuated the releaseindependent short-term depression mechanism present at baseline. To explore this hypothesis, we examined short-term plasticity as the duration $(d)$ between pairs of stimuli was varied (Fig. 2). Recovery from depression in control proceeded in two rising exponential phases with time constants of $\sim 6$ and $\sim 5000 \mathrm{msec}$ (Brody and Yue, unpublished observations). Mennerick and Zorumski (1995) have observed a similar time course previously. Most importantly, in control, there was little change in short-term plasticity for interstimulus intervals between 20 and $420 \mathrm{msec}$ (Fig. 2B, solid squares). In baclofen, however, the second EPSC was larger than the first EPSC at short intervals, but smaller at longer intervals (Fig. 2B, dashed line, open circles). Thus there appeared to be a distinct component of facilitation in baclofen 

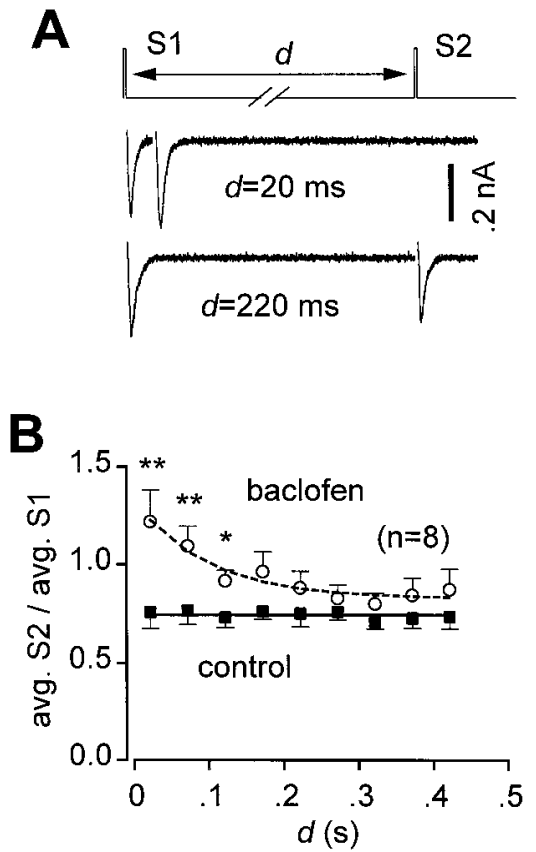

Figure 2. Recovery of synaptic responses between two stimuli $(S 1, S 2)$ in control and in baclofen. $A$, Stimulus protocol (top) and single-sweep exemplars in baclofen. $B$, Averages across cells. Little change in shortterm depression in control (solid squares) is seen during the time intervals examined (20-420 msec). In baclofen (open circles), there was additional facilitation at short intervals, which decayed exponentially (dashed line) with a $96 \mathrm{msec}$ time constant $(95 \%$ confidence interval, $65-180 \mathrm{msec})$. Statistical significance levels: $p<0.005\left({ }^{* *}\right)$ and $p<0.01\left({ }^{*}\right)$. The eight cells contributing to the average recovery data are different from those used in Figure 1.

that decayed rapidly ( $\tau=96 \mathrm{msec}$ ), leaving the subsequent recovery from depression indistinguishable from that of the control over the remaining period in which comparisons were made $(d=170-420 \mathrm{msec})$. These results would be difficult to reconcile with simple attenuation of depression. They fit well, however, with reestablishment of G-protein-mediated inhibition after its relief by the first stimulus (Lopez and Brown, 1991; Zamponi and Snutch, 1998), all superimposed on unchanged baseline depression.

To exclude novel postsynaptic mechanisms underlying the baclofen-induced facilitation, we analyzed miniature EPSCs (minis), which arise from the asynchronous release of single synaptic vesicles. Changes in postsynaptic receptor sensitivity and dendritic attenuation that might produce synaptic plasticity would be apparent as changes in mini amplitudes (Wyllie et al., 1994; Isaac et al., 1996; Carroll et al., 1998). During baseline periods (Fig. $3 A$ ), baclofen did not change either the mean or distribution of mini peak amplitudes (Table 1; Fig. 3B; Kolmogorov-Smirnov test, $p>0.2$ ). A particular advantage of single-neuron cultures is that all minis arise from the same presynaptic cell as evoked EPSCs. In other preparations, minis may reflect release events at numerous synapses outside of the subset that contributes to evoked EPSCs. Therefore, if there were a change in the amplitude of minis originating from this subset, the change might be poorly resolved in the amplitude histogram for minis arising from all synapses. Instead, in single-neuron cultures, the lack of change in mini amplitudes is sufficient to exclude novel postsynaptic mechanisms as the basis for the baclofen effect on evoked EPSCs.

Furthermore, baclofen did not alter average mini amplitudes during a time window stretching from 20 to $100 \mathrm{msec}$ after an

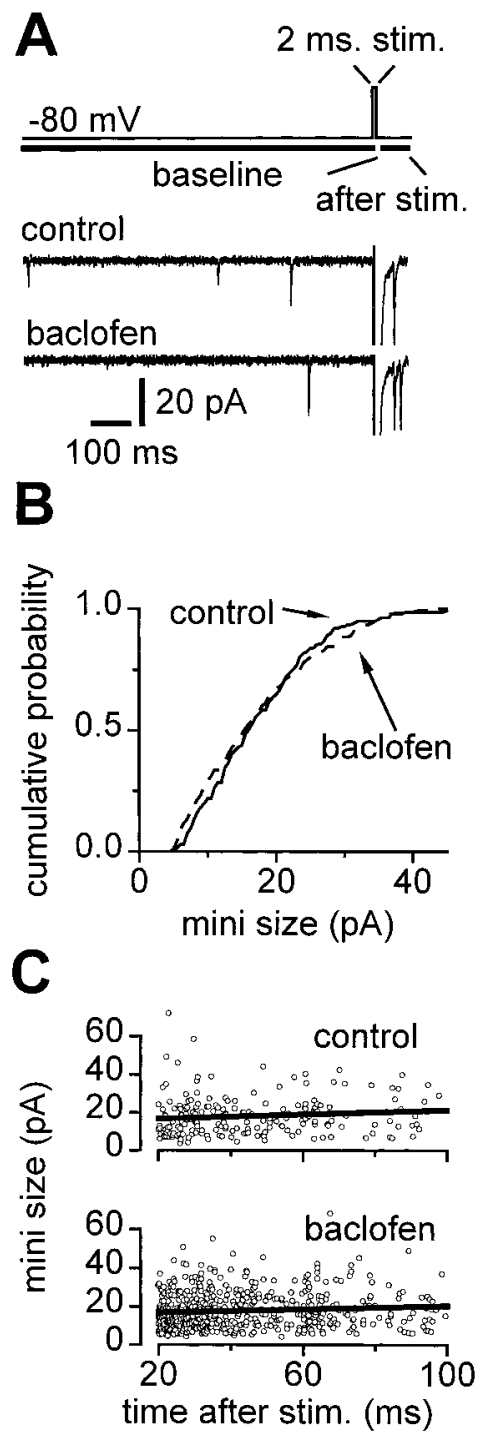

Figure 3. Analysis of minis. A, Stimulus protocol (top) for acquiring minis at baseline and after an evoked EPSC, with sample records in control (middle) and baclofen (bottom). Minis were well resolved after decay of full-sized EPSCs. Full-sized EPSCs have been truncated for clarity. $B$, Distributions of mini sizes at baseline were no different between control (solid line) and baclofen (dashed line; Kolmogorov-Smirnov test, $p>0.2$ ). Plotted on the $y$-axis is the cumulative probability that peak mini amplitudes were smaller than the values on the $x$-axis. $C$, Mini sizes versus time after EPSC-producing stimuli are shown. Mini sizes increased slightly with increasing times after stimuli (solid lines; slope, $0.056 \mathrm{pA} / \mathrm{msec}$ in control, $p<0.001$; slope, $0.044 \mathrm{pA} / \mathrm{msec}$ in baclofen, $p<0.002)$. Slopes are not different between control and baclofen $(p=$ $0.56)$. All data in $B$ and $C$ are from one representative cell.

evoked EPSC (Table 1; Fig. 3C), despite the persistence of baclofen-induced facilitation throughout this period (Fig. 2B). Amplitudes did increase with time after the evoked EPSCs ( $\sim 20 \%$ in $80 \mathrm{msec}$ ), but the increases were indistinguishable between control and baclofen (Fig. 3C). This increase could in no way account for the facilitation that occurred only in baclofen and decayed over the same time interval (Fig. 2B). Thus, these results ruled out a major postsynaptic component as the basis of the facilitation in baclofen.

A final class of alternative mechanisms we examined concerned the possibility that baclofen unmasked activity-dependent but 
Table 1. Characteristics of minis

\begin{tabular}{llll} 
& $\begin{array}{l}\text { Baseline size } \\
(\mathrm{pA})\end{array}$ & $\begin{array}{l}\text { After stimulus } \\
\text { size }(\mathrm{pA})\end{array}$ & $\begin{array}{l}\text { Baseline rate } \\
(\mathrm{Hz})\end{array}$ \\
\hline Control & $15.22 \pm 1.64$ & $15.08 \pm 2.11$ & $1.62 \pm 0.50$ \\
Baclofen & $14.77 \pm 1.36$ & $16.13 \pm 2.26$ & $0.67 \pm 0.21^{*}$
\end{tabular}

Baseline minis were recorded during $1 \mathrm{sec}$ epochs before an EPSC-evoking stimulus. After stimulus minis were recorded between 20 and $100 \mathrm{msec}$ after a $2 \mathrm{msec}$ voltage step that evoked full-sized EPSC. Values are given as means \pm SE $(n=7$ cells). There were no statistically resolvable differences in the amplitudes of minis either at baseline or after stimuli, but baclofen did change the rate of spontaneous minis $\left({ }^{*} p<0.05\right.$ vs control).

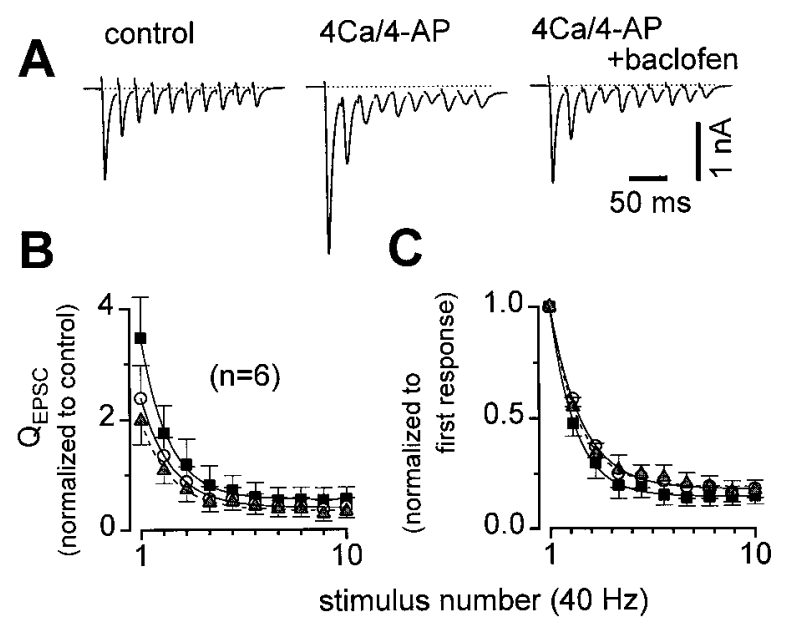

Figure 4. Elevation of presynaptic calcium entry with $4 \mathrm{mM} \mathrm{Ca}^{2+}$ plus $100 \mu \mathrm{M}$ 4-AP (4Ca/4- $A P$ ) blunted inhibition by baclofen or 2-CADO and occluded changes in short-term plasticity. $A$, Synaptic currents showing an increase in EPSC amplitudes in 4Ca/4-AP (middle) and mild effects of 20 $\mu \mathrm{M}$ baclofen in $4 C a / 4-A P$ (right). Averages of 10,13 , and 10 sweeps (left, middle, right, respectively) from the same cell are shown. $B, Q_{\text {EPSC }}$ averages across cells. Data from each cell are normalized by the first $Q_{\text {EPSC }}$ in control (2 $\mathrm{mM} \mathrm{Ca}^{2+}, 1 \mathrm{mM} \mathrm{Mg}^{2+}$, no 4-AP) before averaging. $4 C a / 4-A P(n=6$; solid squares $)$ increased initial EPSCs 3.47 ( \pm 0.73$)$-fold. $4 C a / 4-A P$ plus $20 \mu \mathrm{M}$ baclofen or $2 \mu \mathrm{M} 2-\mathrm{CADO}(n=3$ of each averaged together; open circles) inhibited EPSCs by $34 \pm 6.7 \%$ on average relative to $4 C a / 4-A P$, and $4 C a / 4-A P$ plus $3 \mu \mathrm{M} \mathrm{Cd}^{2+}(n=6$; gray triangles $)$ reduced EPSCs by $42 \pm 6.6 \%$ relative to $4 C a / 4-A P$. $C$, Same data normalized to the first $Q_{\mathrm{EPSC}}$ in each condition to facilitate comparison of short-term synaptic plasticity. No significant differences $(p>0.5$ for all responses) between $\mathrm{Cd}^{2+}$ (gray triangles) and baclofen or 2-CADO (open circles).

$\mathrm{Ca}^{2+}$-independent changes in maximal release probability, downstream of calcium entry. If such a mechanism accounted for the facilitation in baclofen, then this facilitation would be insensitive to raising overall presynaptic calcium entry. Alternatively, if relief of calcium channel inhibition explains the facilitation, it should be blunted with saturation of the Dodge-Rahamimoff relation between calcium influx and vesicle release (Dodge and Rahamimoff, 1967; Reid et al., 1998). In this case, proportionate spike-to-spike increases in presynaptic calcium currents would enhance neurotransmitter release to a lesser extent when absolute calcium current magnitudes are larger. To test this, we increased presynaptic calcium entry mainly (see Materials and Methods) by raising extracellular $\mathrm{Ca}^{2+}$ from 2 to $4 \mathrm{~mm}$ and adding $100 \mu \mathrm{M}$ 4-AP to broaden the presynaptic action potentials (Fig. 4A, 4Ca/4-AP) (Llinas et al., 1976; Wheeler et al., 1996; Hjelmstad et al., 1997). In $4 C a / 4-A P$, initial EPSCs were on average 3.47 -fold larger than in control (Fig. 4B), and baclofen, 2-CADO, and
$\mathrm{Cd}^{2+}$ all inhibited the EPSCs less effectively (compare Fig. $4 B$ with Fig. $1 D$, left). Most importantly, in $4 C a / 4-A P$, baclofen or 2-CADO caused only small changes in short-term plasticity (Fig. $4 C$ ), thereby excluding progressive changes in maximal release probability as the mechanism of facilitation. These results support other mechanisms, including relief of G-protein-mediated inhibition, presynaptic action potential changes, and spike-to-spike increases in the calcium affinity of the release apparatus.

\section{Blockade of $\mathrm{N}$ - versus $\mathrm{P} / \mathrm{Q}$-type channels results in predicted differential effects on short-term synaptic plasticity}

To generate a highly discriminating test of whether relief of G-protein-mediated inhibition underlies the facilitation, we hoped to exploit a clear intrinsic difference between the two types of presynaptic calcium channels that trigger transmitter release (Takahashi and Momiyama, 1993; Wheeler et al., 1994; Reuter, 1995; Reid et al., 1997). One such distinction was apparent between recombinant P/Q-type $\left(\alpha_{1 \mathrm{~A}}\right)$ and N-type $\left(\alpha_{1 \mathrm{~B}}\right)$ channels expressed in HEK 293 cells along with M2 muscarinic acetylcholine receptors (Fig. 5). M2 receptor activation by carbachol, an acetylcholine analog, inhibited $\mathrm{P} / \mathrm{Q}$ - and N-type channels to comparable extents $(27 \pm 5$ and $36 \pm 8 \%$, respectively). However, 50 $\mathrm{Hz}$ trains of voltage-clamp action potential waveforms (APWs) relieved more of the inhibition of P/Q-type (Fig. $5 A, C$, left, $D$ ) than of N-type (Fig. 5B,C, right, D) channels. Voltage pulses to $+100 \mathrm{mV}$ relieved inhibition nearly completely in both channel types (92\% for N-type; $95 \%$ for P/Q-type). Thus the differing behavior of channel types during trains reflected distinctions in the kinetics of relief and not in the voltage-dependent nature of the inhibition. Furthermore, these distinctions between P/Q- and $\mathrm{N}$-type channels were not unique to the particular combination of auxiliary subunits used in these experiments. The stronger relief of G-protein-mediated inhibition shown by $\mathrm{P} / \mathrm{Q}$-type channels was qualitatively preserved when either the $\beta_{1 \mathrm{~b}}$ or $\beta_{3}$ subunit was substituted for the $\beta_{2 \mathrm{a}}$ subunit used in the experiments shown in Figure 5 (data not shown), after taking into account the overall changes in baseline inactivation properties seen with these other subunits (Patil et al., 1998). Assuming that the contrasting features of M2 receptor-mediated inhibition of P/Q- and N-type channels in HEK 293 cells would hold true for baclofen-induced channel inhibition in hippocampal neurons, we made the following specific prediction: if relief of G-protein-mediated inhibition produces the facilitation seen in baclofen, then the facilitation should be larger for transmission mediated exclusively by P/Qtype channels than for transmission mediated by $\mathrm{N}$-type channels.

To test this key prediction, we compared the effects of baclofen during selective blockade of N-type channels with those during blockade of P/Q-type channels. Synaptic transmission via P/Qtype channels was isolated with $\omega \mathrm{Ctx}-\mathrm{GVIA}$, a peptide toxin that selectively blocks N-type channels (Dunlap et al., 1995; Mori et al., 1996). During steady-state $\omega$ Ctx-GVIA blockade (Fig. 6A), baclofen still inhibited transmission by $70 \pm 4 \%(n=7)$, and short-term depression was reduced or converted to facilitation (Fig. 6A,C, left, D), as in the absence of toxins (Fig. 1). In separate cells, N-type channel-mediated transmission was isolated with $\omega$ Aga-IVA, a peptide inhibitor of both P- and Q-type channels (Dunlap et al., 1995; Mori et al., 1996). After wAga-IVA blockade (Fig. 6B), baclofen inhibited neurotransmission by an additional $73 \pm 4 \%(n=6)$. In contrast to the results with isolated $\mathrm{P} / \mathrm{Q}$-type channels (Fig. 6A), baclofen caused little change in short-term plasticity when only N-type channels triggered trans- 
Figure 5. Recombinant P/Q-type calcium channels show more relief of G-protein-mediated inhibition than do N-type channels. Cloned calcium channels were expressed in HEK 293 cells along with M2 receptors, and calcium currents were evoked using $50 \mathrm{~Hz}$ trains of voltage-clamped APWs that started from a base potential of $-80 \mathrm{mV}$, peaked at +30 $\mathrm{mV}$, and lasted $1.5 \mathrm{msec}$ at half-amplitude. The waveforms were based on those recorded in the calyx of Held (Borst et al., 1995) but were scaled in amplitude and duration to the parameters mentioned above. The half-width duration of 1.5 msec was approximately threefold longer than originally recorded in the calyx, to accord with the duration of action potentials measured in cultured neuron somata, whose halfwidths averaged $\sim 1.42 \mathrm{msec}$ (Brody and Yue, unpublished observations). $A, \mathrm{P} / \mathrm{Q}$-type channel currents $\left(\alpha_{1 \mathrm{~A}} \beta_{2 \mathrm{a}} \alpha_{2} \delta\right)$ showing progressive increases in current (arrow) during G-protein-mediated inhibition by $50 \mu \mathrm{M}$ carbachol $(\mathrm{CCh})$. Little change in the calcium currents in control solutions during APW trains (top). $B$, N-type channel records $\left(\alpha_{1 B} \beta_{2}\right.$ $\alpha_{2} \delta$ ) showing little relief of G-protein-mediated inhibition (arrow). $C$, Peak currents $\left(I_{\mathrm{PEAK}}\right)$ averaged across cells in control (solid squares) or carbachol (open circles). Normalization is by the first peak current in each cell before averaging. $D$, Ratios of carbachol to control peak currents $\left(I_{\mathrm{CCh}} / I_{\text {control }}\right)$ providing direct comparison of relief of G-protein-mediated inhibition between P/Q-type channels (open triangles) and N-type channels (solid diamonds). Normalization is by the first ratios in each cell before averaging.

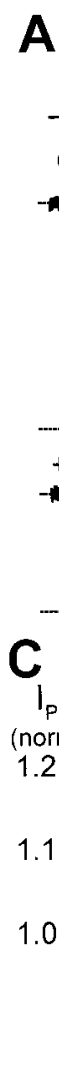

A P/Q-type $\left(\alpha_{1 A}\right)$
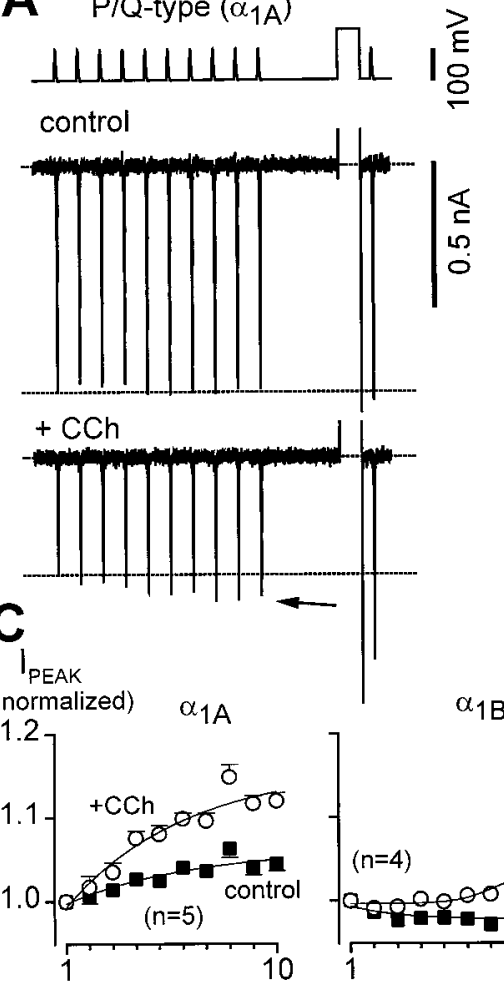

B $\quad$-type $\left(\alpha_{1 B}\right)$

$60 \mathrm{~ms}$
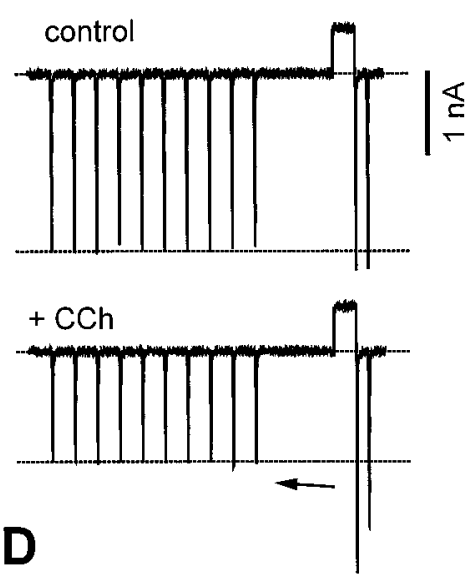

$\mathrm{I}_{\mathrm{CCh}} / \mathrm{I}_{\text {control }}$

(normalized) mission (Fig. 6B, $C$, right, $D$ ). The distinction between the effects of baclofen with the two toxins was actually greater than might be expected from our studies of recombinant channels, even after factoring in a standard third to fourth power relationship between $\mathrm{Ca}^{2+}$ current and EPSCs. Quantitative differences between the extents of facilitation in the cultured neurons and HEK 293 cells could reflect differences in the nature of the G-proteins or in the parameters of action potentials. These parameters may change during repetitive presynaptic firing but were held fixed in experiments with recombinant channels. Overall, the remarkable agreement of these results with our prediction strongly supported the hypothesis that relief of G-protein-mediated inhibition of calcium channels underlies the short-term synaptic facilitation observed in the presence of baclofen.

The experiments summarized in Figure 6 merit an important technical clarification. To conserve on expenditure of toxins, we stopped toxin application before baclofen exposure (e.g., Fig. $6 A, B)$. Nonetheless, the baclofen experiments can be interpreted as if steady-state toxin blockade were still in effect, because these experiments were always performed within an $\sim 5$ min window shortly after toxin application, and control experiments showed almost no reversal of blockade over this time span. In such 5 min windows, there was $-0.1 \pm 0.96 \%$ recovery of pretoxin currents after cessation of $\omega \mathrm{Ctx}-\mathrm{GVIA}(n=4$ cells $)$ and $-1.89 \pm 2.3 \%$ recovery after $\omega$ Aga-IVA ( $n=3$ cells). Hence, the conclusions based on results in Figure 6 are no different from those that would be drawn using continuous toxin application.

\section{DISCUSSION}

This report is the first that specifically implicates a contribution of relief of G-protein-mediated inhibition to synaptic plasticity. This form of relative facilitation is distinct from the mechanisms of short-term facilitation that have been described in other prepa- rations. Presynaptic calcium channels in the calyx of Held exhibit a $\mathrm{Ca}^{2+}$ entry-dependent form of facilitation that contributes to short-term synaptic plasticity (Borst and Sakmann, 1998; Cuttle et al., 1998), but this effect may involve the action of $\mathrm{Ca}^{2+}$ calmodulin (Lee et al., 1999) and does not require G-protein activation. Others have shown that STD can be attenuated by an overall reduction of neurotransmitter release, yielding a relative facilitation (Lev-Tov and Pinco, 1992; Barnes-Davies and Forsythe, 1995; Isaacson and Hille, 1997; Varela et al., 1997). However, these effects on STD were attributable to release-dependent mechanisms such as vesicle depletion (Zucker, 1989). At an avian calyceal synapse, such attenuation of STD can in fact result in frank facilitation of synaptic responses during high-frequency stimulation, with concomitant increases in the likelihood of firing postsynaptic action potentials (Brenowitz et al., 1998). By contrast, in hippocampal autapses, we have found that G-proteinmediated inhibition reduces STD or converts it to relative facilitation, in a manner that is consistent with relief of G-proteinmediated inhibition of calcium channels but not with $\mathrm{Ca}^{2+}$ dependent facilitation or attenuation of release-dependent depression.

Have there been previously reported hints of a mechanism such as that observed here? At the same avian synapses, conversion of paired-pulse depression to facilitation by baclofen inhibition could have resulted in part from relief of G-protein-mediated inhibition, because comparable $\mathrm{Cd}^{2+}$-mediated inhibition occluded depression but produced less facilitation (Otis and Trussell, 1996). Also, in rat hippocampal slice cultures, adenosine inhibited transmission and increased paired-pulse facilitation. Although lowering $\left[\mathrm{Ca}^{2+}\right]_{0}$ and increasing $\left[\mathrm{Mg}^{2+}\right]_{\mathrm{o}}$ inhibited transmission more than did adenosine, this maneuver increased paired-pulse facilitation less than did adenosine (Debanne et al., 
A
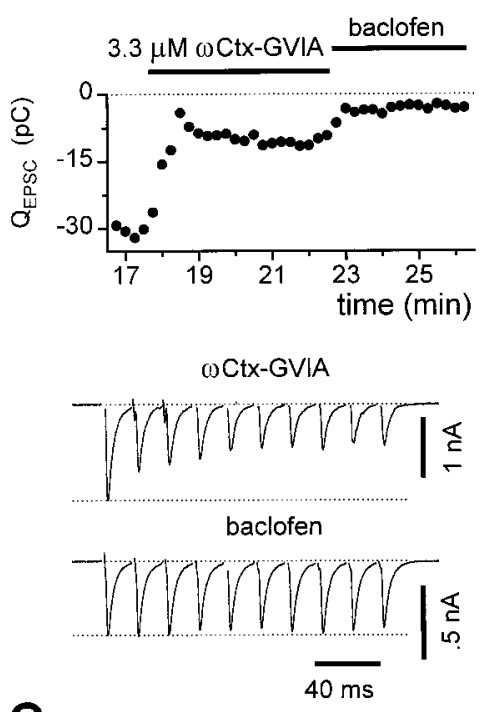

C

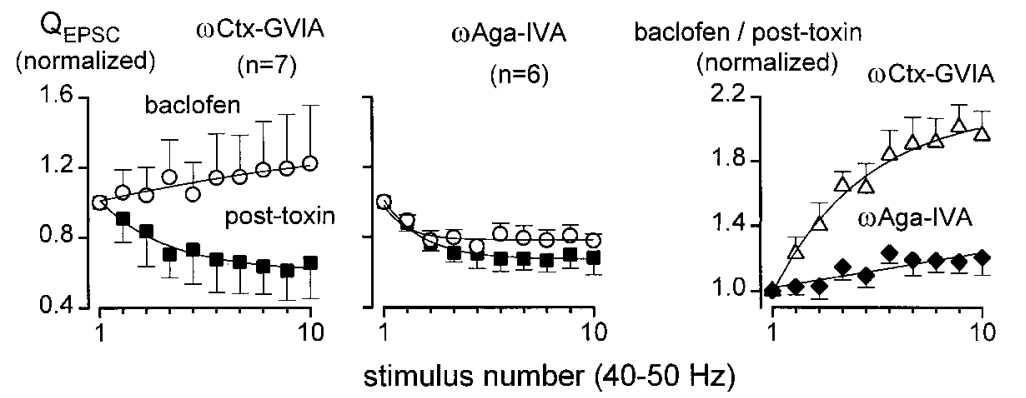

Figure 6. Synaptic facilitation during G-protein-mediated inhibition is larger for transmission mediated by $\mathrm{P} / \mathrm{Q}$-type channels than for transmission mediated by $\mathrm{N}$-type channels. $A$, Blocking N-type channels to isolate neurotransmission via $\mathrm{P} / \mathrm{Q}$-type calcium channels is shown. Top, First $Q_{\text {EPSC }}$ before and during blockade by $\omega \mathrm{Ctx}-\mathrm{GVIA}$, a selective blocker of $\mathrm{N}$-type calcium channels. Average inhibition was $63 \pm 11 \%$ $(n=7)$, and average time to half-block was $37 \pm 13 \mathrm{sec}(n=$ 6). Baclofen further inhibited synaptic transmission. Middle, Synaptic currents evoked by a $50 \mathrm{~Hz}$ train in $\omega \mathrm{Ctx}$-GVIA (single sweep) are shown. Bottom, Baclofen application during toxin blockade still shifted short-term plasticity toward facilitation (average of 19 sweeps; same cell as above). B, Blocking P/Q-type channels to isolate neurotransmission via $\mathrm{N}$-type channels. Top, Blockade by $\omega$ Aga-IVA, a selective blocker of $\mathrm{P} / \mathrm{Q}$-type calcium channels, is shown. Average inhibition was $79 \pm 5 \%(n=6)$, and average time to halfblock was $210 \pm 71 \mathrm{sec}(n=6)$. Inset, Expanded $y$-axis shows inhibition by baclofen after toxin block. Middle, Synaptic currents evoked by a $40 \mathrm{~Hz}$ train in $\omega$ Aga-IVA (single sweep) are shown. Bottom, During toxin blockade, baclofen inhibited EPSCs but had little effect on short-term synaptic plasticity (average of 19 sweeps; same cell as above). C, Effects of baclofen on short-term plasticity after $\omega \mathrm{Ctx}$-GVIA block $(l e f t)$ and after $\omega$ Aga-IVA block (right). Normalized $Q_{\text {EPSC }}$ averages across cells in control solution after toxin application (solid squares) and in baclofen after toxin application (open circles) are shown. After $\omega \mathrm{Ctx}$-GVIA block, short-term plasticity in baclofen was significantly different from control $(p<0.01)$ for stimuli 4 and $6-10$. After $\omega$ Aga-IVA block, plasticity in baclofen was not significantly different from control $(p>0.05)$ except on stimuli 6,8 , and $9(p=0.008-0.04)$. $D$, Direct comparison of changes in short-term plasticity in baclofen after $\omega \mathrm{Ctx}$-GVIA block (open triangles) and after $\omega$ Aga-IVA block (solid diamonds). Ratios of baclofen to control normalized $Q_{\text {EPSC }}$ data from $C$ (baclofen/post-toxin) are averaged across cells. Differences are significant $(p<0.05)$ for stimuli $3-10$.
1996). Finally, in frog sympathetic ganglia, synaptic depression caused by acetylcholine autoinhibition was prominent during 5 $\mathrm{Hz}$ stimulation, but not at $20 \mathrm{~Hz}$ (Shen and Horn, 1996). The authors proposed that $20 \mathrm{~Hz}$ stimulation could have relieved the inhibition of presynaptic calcium channels, whereas $5 \mathrm{~Hz}$ action potentials did not. One important difference between some previous results and ours is that the baseline depression in cultured hippocampal neurons was not detectably release dependent. This unusual finding has been investigated in a separate set of experiments, which supports axonal branch-point failure (Parnas, 1972; Hatt and Smith, 1976; Macagno et al., 1987; Streit et al., 1992; Wall, 1995; Debanne et al., 1997) as the underlying mechanism for the short-term synaptic depression (Brody and Yue, unpublished observations). Regardless of the mechanism, the releaseindependent nature of the baseline depression clarified the interpretation of changes in short-term plasticity during G-proteinmediated inhibition of calcium channels.

Another key aspect of our approach concerns the use of $\mathrm{Cd}^{2+}$ to test for release-dependent mechanisms by reducing presynaptic $\mathrm{Ca}^{2+}$ influx. Both G-protein-mediated inhibition and $\mathrm{Cd}^{2+}$ blockade of calcium channels in effect reduce channel open probability without altering unitary current amplitude; $\mathrm{Cd}^{2+}$ at low doses produces a millisecond flickering block of calcium channels (Lansman et al., 1986), whereas G-protein-mediated inhibition of neuronal calcium channels slows the activation of channels (Carabelli et al., 1996; Patil et al., 1996). An advantageous distinction between G-protein-mediated inhibition and $\mathrm{Cd}^{2+}$ blockade is that the former can be relieved during repetitive activity (e.g., Fig.
$5 A$ ) but $\mathrm{Cd}^{2+}$ blockade remains invariant during analogous trains of APWs (Fig. 7). Here, the patterns of short-term changes in recombinant $\mathrm{P} / \mathrm{Q}$ - or $\mathrm{N}$-type currents did not change after robust blockade by $\mathrm{Cd}^{2+}$. The invariance of $\mathrm{Cd}^{2+}$ blockade during repetitive activity probably arises from the relative voltage independence of $\mathrm{Cd}^{2+}$ blockade of neuronal channels over a physiological range of voltages (Leonard et al., 1987). When voltagedependent unblock of $\mathrm{Cd}^{2+}$ in neuronal calcium channels has been observed (Thevenod and Jones, 1992), it was not apparent for voltages up to $+40 \mathrm{mV}$ and manifested clearly only with stronger (unphysiological) depolarization.

Changing extracellular calcium and/or magnesium concentrations to test for release-dependent mechanisms may not be equivalent to $\mathrm{Cd}^{2+}$ blockade. Altering $\mathrm{Ca}^{2+}$ or $\mathrm{Mg}^{2+}$ alters unitary channel conductance (Church and Stanley, 1996), which may have distinct effects on calcium concentrations in presynaptic microdomains. Also, changes in these divalent cations may alter membrane excitability by surface-charge-screening effects (Frankenhaeuser and Hodgkin, 1957), which appears to affect various ion channels inhomogeneously (Green and Andersen, 1991). The low doses of $\mathrm{Cd}^{2+}$ required to block calcium channels do not produce detectable surface-charge effects, as gauged by the voltage required for either half-activation of calcium channels (Leonard et al., 1987) or half-inactivation of sodium channels (Hanck and Sheets, 1992). Furthermore, the micromolar concentrations of $\mathrm{Cd}^{2+}$ used in this study had no measurable effect on action potentials measured in hippocampal somata, with half-width durations of $1.42 \pm 0.16 \mathrm{msec}$ in control versus $1.39 \pm 0.14 \mathrm{msec}$ in 


\section{A}

Figure 7. Recombinant $\mathrm{P} / \mathrm{Q}-$ and $\mathrm{N}$-type calcium channels show activity-independent blockade by $\mathrm{Cd}^{2+}$. Cloned calcium channels were expressed in HEK 293 cells, and calcium currents were evoked using $50 \mathrm{~Hz}$ trains of action potential waveforms, as in Figure 5. $A, \mathrm{P} / \mathrm{Q}$-type channel currents $\left(\alpha_{1 \mathrm{~A}} \beta_{4} \alpha_{2} \delta\right)$ were partially blocked by $2 \mu \mathrm{M} \mathrm{Cd}^{2+}$. There were no apparent changes in the amplitudes of the currents with repetitive stimuli either in control or in $\mathrm{Cd}^{2+} . B$, N-type channels coexpressed with a $\beta$ subunit favoring inactivation $\left(\alpha_{1 \mathrm{~B}} \beta_{3} \alpha_{2} \delta\right)$ were also partially blocked by $2 \mu \mathrm{M} \mathrm{Cd}{ }^{2+}$, and there were no changes in the extent of inactivation during $\mathrm{Cd}^{2+}$ blockade. Scale bars apply to both $A$ and $B$. Displayed are averages of four sweeps (control) and eight sweeps $\left(\mathrm{Cd}^{2+}\right)$ for both $A$ and $B . C$, Normalized peak current amplitudes from $\mathrm{P} / \mathrm{Q}$-type channel records, averaged from the same cell shown in $A$. No significant differences between control (solid squares) and $\mathrm{Cd}^{2+}$ (open circles). D, Normalized peak currents from N-type channel records, averaged from the same cell shown in $B$. The analysis in $C$ and $D$ confirmed the activity-independent nature of $\mathrm{Cd}^{2+}$ blockade of both neuronal calcium channel types.
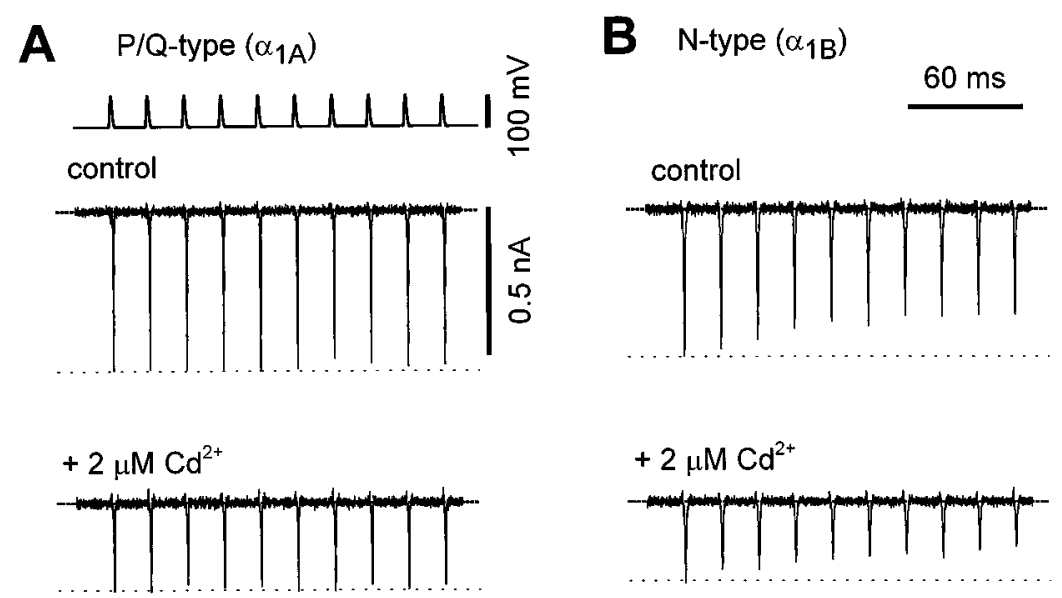

C

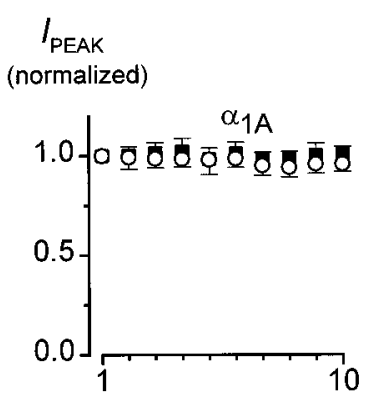

D
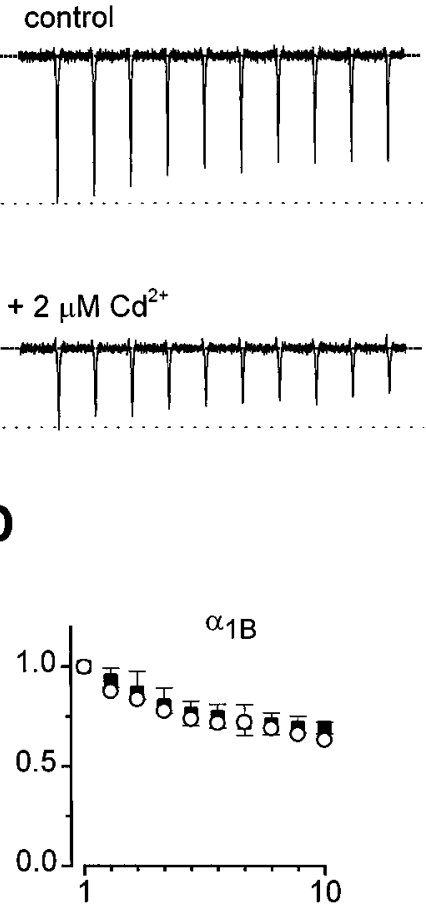

stimulus number $(50 \mathrm{~Hz})$
$2 \mu \mathrm{M} \mathrm{Cd}^{2+}(n=5$ cells; $p>0.40)$. These distinctions are relevant to the present results, because changing $\mathrm{Ca}^{2+}$ and/or $\mathrm{Mg}^{2+}$ does affect short-term synaptic plasticity in this preparation (Mennerick and Zorumski, 1995), but in a complex manner that is inconsistent with the presence of release-dependent depression (Brody and Yue, unpublished observations). Thus, the use of $\mathrm{Cd}^{2+}$ allowed us to exclude unambiguously several potential alternative explanations for the effects of baclofen on short-term synaptic plasticity.

Although baclofen did not show discernible postsynaptic effects (Fig. 3; Table 1), it did reduce the rate of spontaneous EPSCs from $1.62 \mathrm{~Hz}$ in control to $0.67 \mathrm{~Hz}$ in baclofen (Table 1). In other preparations, presynaptic inhibition has similar effects (Scanziani et al., 1992; Dittman and Regehr, 1996), which have been hypothesized to involve an inhibitory effect on the release machinery downstream of $\mathrm{Ca}^{2+}$ entry. Although this effect merits future investigation, it is unlikely to contribute to the relative facilitation produced by baclofen. First, a tonic decrease in overall release probability, such as might be inferred from the decrease in mini frequency, would not be expected to give rise to facilitation in the autapse preparation, because of the evidence favoring releaseindependent short-term depression (i.e., Fig. 1, the experiments with $\mathrm{Cd}^{2+}$ ). Second, effects on the release machinery downstream of $\mathrm{Ca}^{2+}$ entry could not account for the near occlusion of baclofen-induced facilitation after blockade of $\mathrm{P} / \mathrm{Q}$-type channels (Fig. 6).

One final alternate mechanism that we have not considered is the potential interaction of baclofen with the rab protein pathway (Simons and Zerial, 1993; Fischer von Mollard et al., 1994). Rab proteins are small GTP-binding proteins that may catalyze GTP hydrolysis in the course of facilitating vesicle docking and/or priming (Sudhof, 1995). Activation of G-protein-coupled receptors by baclofen could in principle decrease local GTP concentrations and thereby reduce vesicle docking and/or repriming. Although this could conceivably affect short-term synaptic plasticity, G-protein-coupled receptor activation should, if anything, enhance short-term depression. Instead we found experimentally that baclofen had just the opposite effect, shifting short-term plasticity toward facilitation. Furthermore, the involvement of rab proteins could in no way explain the differential effects on shortterm responses produced by blockade of $\mathrm{N}$ - versus $\mathrm{P} / \mathrm{Q}$-type channels. Hence, it seems unlikely that changes in rab protein cycling underlie the baclofen-induced changes in synaptic plasticity.

The form of short-term synaptic plasticity described here could have important implications for neuronal information processing. G-protein-mediated presynaptic inhibition may not cause an absolute quieting of the synapse but rather a selective damping of low-frequency activity. Information carried in high-frequency bursts of action potentials (Connors and Gutnick, 1990; Gray and McCormick, 1996; Lisman, 1997) may still be transferred reliably, because such bursts could partially reverse the inhibition. This could be a widespread phenomenon, because autosynaptic and heterosynaptic inhibition by a variety of neurotransmitters, as well as tonic adenosine receptor activation, act via G-proteinmediated inhibition of presynaptic calcium channels (Anwyl, 1991; Jones and Elmslie, 1997). For example, the diffusion of GABA from its site of release to presynaptic terminals on glutamate-releasing synapses in CNS slices has been shown to heterosynaptically inhibit excitatory transmission via activation of $\mathrm{GABA}_{\mathrm{B}}$ receptors (Isaacson et al., 1993; Dittman and Regehr, 1997). Such inhibition could significantly alter short-term plasticity at the affected excitatory synapses, at least in part due to relief 
of G-protein inhibition. Likewise, presynaptic G-protein-coupled autoreceptors can be activated by transmitter released from the same synapse, inhibiting further transmitter release (Deisz and Prince 1989; Scanziani et al., 1997). Relief of G-protein inhibition could limit the magnitude of this sort of negative feedback during high-frequency firing. Additionally, tonic G-protein inhibition may occur because of the presence of extracellular adenosine in slice preparations (Wu and Saggau, 1994; Masino and Dunwiddie, 1999). Therefore, relief of G-protein inhibition may underlie a portion of the baseline short-term plasticity at some synapses. Thus, this frequency-selective mechanism may affect many aspects of synaptic function throughout the nervous system. Inhibition by adenosine has been implicated in the regulation of arousal and wakefulness in vivo (Porkka-Heiskanen et al., 1997), and it will be interesting to investigate the role of possible concomitant changes in short-term synaptic plasticity in more intact systems.

\section{REFERENCES}

Abbott LF, Varela JA, Sen K, Nelson SB (1997) Synaptic depression and cortical gain control. Science 275:220-224.

Anwyl R (1991) Modulation of vertebrate neuronal calcium channels by transmitters. Brain Res Brain Res Rev 16:265-281.

Atluri PP, Regehr WG (1996) Determinants of the time course of facilitation at the granule cell to Purkinje cell synapse. J Neurosci 16:5661-5671.

Barnes-Davies M, Forsythe ID (1995) Pre- and postsynaptic glutamate receptors at a giant excitatory synapse in rat auditory brainstem slices. J Physiol (Lond) 488:387-406.

Bean BP (1989) Neurotransmitter inhibition of neuronal calcium currents by changes in channel voltage dependence. Nature 340:153-156.

Bekkers JM, Stevens CF (1991) Excitatory and inhibitory autaptic currents in isolated hippocampal neurons maintained in cell culture. Proc Natl Acad Sci USA 88:7834-7838.

Borst JG, Sakmann B (1998) Facilitation of presynaptic calcium currents in the rat brainstem. J Physiol (Lond) 513:149-155.

Borst JG, Helmchen F, Sakmann B (1995) Pre- and postsynaptic wholecell recordings in the medial nucleus of the trapezoid body of the rat. J Physiol (Lond) 487:825-840.

Brenowitz S, David J, Trussell L (1998) Enhancement of synaptic efficacy by presynaptic GABA(B) receptors. Neuron 20:135-141.

Brody DL, Patil PG, Mulle JG, Snutch TP, Yue DT (1997) Bursts of action potential waveforms relieve G-protein inhibition of recombinant P/Q-type $\mathrm{Ca}^{2+}$ channels in HEK 293 cells. J Physiol (Lond) 499:637-644.

Carabelli V, Lovallo M, Magnelli V, Zucker H, Carbone E (1996) Voltage-dependent modulation of single $\mathrm{N}$-Type $\mathrm{Ca}^{2+}$ channel kinetics by receptor agonists in IMR32 cells. Biophys J 70:2144-2154.

Carroll RC, Nicoll RA, Malenka RC (1998) Effects of PKA and PKC on miniature excitatory postsynaptic currents in CA1 pyramidal cells. J Neurophysiol 80:2797-2800.

Castellano A, Wei X, Birnbaumer L, Perez-Reyes E (1993a) Cloning and expression of a third calcium channel beta subunit. J Biol Chem 268:3450-3455.

Castellano A, Wei X, Birnbaumer L, Perez-Reyes E (1993b) Cloning and expression of a neuronal calcium channel beta subunit. J Biol Chem 268:12359-12366.

Charlton MP, Smith SJ, Zucker RS (1982) Role of presynaptic calcium ions and channels in synaptic facilitation and depression at the squid giant synapse. J Physiol (Lond) 323:173-193.

Church PJ, Stanley EF (1996) Single L-type calcium channel conductance with physiological levels of calcium in chick ciliary ganglion neurons. J Physiol (Lond) 496:59-68.

Connors BW, Gutnick MJ (1990) Intrinsic firing patterns of diverse neocortical neurons. Trends Neurosci 13:99-104.

Cuttle MF, Tsujimoto T, Forsythe ID, Takahashi T (1998) Facilitation of the presynaptic calcium current at an auditory synapse in rat brainstem. J Physiol (Lond) 512:723-729.

Debanne D, Guerineau NC, Gahwiler BH, Thompson SM (1996) Paired-pulse facilitation and depression at unitary synapses in rat hippocampus: quantal fluctuation affects subsequent release. J Physiol (Lond) 491:163-176.

Debanne D, Guerineau NC, Gahwiler BH, Thompson SM (1997)
Action-potential propagation gated by an axonal I(A)-like $\mathrm{K}^{+}$conductance in hippocampus. Nature 389:286-289.

Deisz RA, Prince DA (1989) Frequency-dependent depression of inhibition in guinea-pig neocortex in vitro by $\mathrm{GABA}_{\mathrm{B}}$ receptor feed-back on GABA release. J Physiol (Lond) 412:513-541.

Dittman JS, Regehr WG (1996) Contributions of calcium-dependent and calcium-independent mechanisms to presynaptic inhibition at a cerebellar synapse. J Neurosci 16:1623-1633.

Dittman JS, Regehr WG (1997) Mechanism and kinetics of heterosynaptic depression at a cerebellar synapse. J Neurosci 17:9048-9059.

Dobrunz LE, Stevens CF (1999) Response of hippocampal synapses to natural stimulation patterns. Neuron 22:157-166.

Dodge Jr FA, Rahamimoff R (1967) Co-operative action of calcium ions in transmitter release at the neuromuscular junction. J Physiol (Lond) 193:419-432.

Dunlap K, Luebke JI, Turner TJ (1995) Exocytotic $\mathrm{Ca}^{2+}$ channels in mammalian central neurons. Trends Neurosci 18:89-98.

Elmslie KS, Zhou W, Jones SW (1990) LHRH and GTP-gamma-S modify calcium current activation in bullfrog sympathetic neurons. Neuron 5:75-80.

Fischer von Mollard G, Stahl B, Khokhlatchev A, Sudhof TC, Jahn R (1994) Rab3C is a synaptic vesicle protein that dissociates from synaptic vesicles after stimulation of exocytosis. J Biol Chem 269:10971-10974.

Forsythe ID, Tsujimoto T, Barnes-Davies M, Cuttle MF, Takahashi T (1998) Inactivation of presynaptic calcium current contributes to synaptic depression at a fast central synapse. Neuron 20:797-807.

Frankenhaeuser B, Hodgkin AL (1957) The action of calcium on the electrical properties of squid axons. J Physiol (Lond) 137:218-244.

Furshpan EJ, Landis SC, Matsumoto SG, Potter DD (1986) Synaptic functions in rat sympathetic neurons in microcultures. I. Secretion of norepinephrine and acetylcholine. J Neurosci 6:1061-1079.

Goda Y, Stevens CF (1996) Long-term depression properties in a simple system. Neuron 16:103-111.

Gray CM, McCormick DA (1996) Chattering cells: superficial pyramidal neurons contributing to the generation of synchronous oscillations in the visual cortex. Science 274:109-113.

Green WN, Andersen OS (1991) Surface charges and ion channel function. Annu Rev Physiol 53:341-359.

Hanck DA, Sheets MF (1992) Extracellular divalent and trivalent cation effects on sodium current kinetics in single canine cardiac Purkinje cells. J Physiol (Lond) 454:267-298.

Hatt H, Smith DO (1976) Synaptic depression related to presynaptic axon conduction block. J Physiol (Lond) 259:367-393.

Hjelmstad GO, Nicoll RA, Malenka RC (1997) Synaptic refractory period provides a measure of probability of release in the hippocampus. Neuron 19:1309-1318.

Hochner B, Parnas H, Parnas I (1991) Effects of intra-axonal injection of $\mathrm{Ca}^{2+}$ buffers on evoked release and on facilitation in the crayfish neuromuscular junction. Neurosci Lett 125:215-218.

Isaac JT, Oliet SH, Hjelmstad GO, Nicoll RA, Malenka RC (1996) Expression mechanisms of long-term potentiation in the hippocampus. J Physiol (Paris) 90:299-303.

Isaacson JS, Hille B (1997) GABA(B)-mediated presynaptic inhibition of excitatory transmission and synaptic vesicle dynamics in cultured hippocampal neurons. Neuron 18:143-152.

Isaacson JS, Solis JM, Nicoll RA (1993) Local and diffuse synaptic actions of GABA in the hippocampus. Neuron 10:165-175.

Johnson MD, Yee AG (1995) Ultrastructure of electrophysiologicallycharacterized synapses formed by serotonergic raphe neurons in culture. Neuroscience 67:609-623.

Jones SW, Elmslie KS (1997) Transmitter modulation of neuronal calcium channels. J Membr Biol 155:1-10.

Lansman JB, Hess P, Tsien RW (1986) Blockade of current through single calcium channels by $\mathrm{Cd}^{2+}, \mathrm{Mg}^{2+}$, and $\mathrm{Ca}^{2+}$. Voltage and concentration dependence of calcium entry into the pore. J Gen Physiol 88:321-347.

Lee A, Wong ST, Gallagher D, Li B, Storm DR, Scheuer T, Catterall WA (1999) $\mathrm{Ca}^{2+} /$ calmodulin binds to and modulates P/Q-type calcium channels. Nature 399:155-159.

Leonard JP, Nargeot J, Snutch TP, Davidson N, Lester HA (1987) Ca channels induced in Xenopus oocytes by rat brain mRNA. J Neurosci $7: 875-881$.

Lev-Tov A, Pinco M (1992) In vitro studies of prolonged synaptic depression in the neonatal rat spinal cord. J Physiol (Lond) 447:149-169.

Lisman JE (1997) Bursts as a unit of neural information: making unreliable synapses reliable. Trends Neurosci 20:38-43. 
Llinas R, Walton K, Bohr V (1976) Synaptic transmission in squid giant synapse after potassium conductance blockage with external 3- and 4-aminopyridine. Biophys J 16:83-86.

Lopez HS, Brown AM (1991) Correlation between G protein activation and reblocking kinetics of $\mathrm{Ca}^{2+}$ channel currents in rat sensory neurons. Neuron 7:1061-1068.

Luebke JI, Dunlap K (1994) Sensory neuron N-type calcium currents are inhibited by both voltage-dependent and -independent mechanisms. Pflügers Arch 428:499-507.

Macagno ER, Muller KJ, Pitman RM (1987) Conduction block silences parts of a chemical synapse in the leech central nervous system. J Physiol (Lond) 387:649-664.

Magleby KL (1987) Short-term changes in synaptic efficacy. In: Synaptic function (Edelman GM, Gall WE, Cowan WM, eds), pp 21-56. New York: Wiley.

Markram H, Tsodyks M (1996) Redistribution of synaptic efficacy between neocortical pyramidal neurons. Nature 382:807-810.

Masino SA, Dunwiddie TV (1999) Temperature-dependent modulation of excitatory transmission in hippocampal slices is mediated by extracellular adenosine. J Neurosci 19:1932-1939.

Mennerick S, Zorumski CF (1995) Paired-pulse modulation of fast excitatory synaptic currents in microcultures of rat hippocampal neurons. J Physiol (Lond) 488:85-101.

Mori Y, Mikala G, Varadi G, Kobayashi T, Koch S, Wakamori M, Schwartz A (1996) Molecular pharmacology of voltage-dependent calcium channels. Jpn J Pharmacol 72:83-109.

Otis TS, Trussell LO (1996) Inhibition of transmitter release shortens the duration of the excitatory synaptic current at a calyceal synapse. J Neurophysiol 76:3584-3588.

Pandit SM, Wu S-M (1990) Time series and system analysis with applications. Reprint with corrections. Malabar, FL: Krieger.

Park D, Dunlap K (1998) Dynamic regulation of calcium influx by G-proteins, action potential waveform, and neuronal firing frequency. J Neurosci 18:6757-6766.

Parnas I (1972) Differential block at high frequency of branches of a single axon innervating two muscles. J Neurophysiol 35:903-914.

Patil PG, de Leon M, Reed RR, Dubel S, Snutch TP, Yue DT (1996) Elementary events underlying voltage-dependent G-protein inhibition of N-type calcium channels. Biophys J 71:2509-2521.

Patil PG, Brody DL, Yue DT (1998) Preferential closed-state inactivation of neuronal calcium channels. Neuron 20:1027-1038.

Peralta EG, Ashkenazi A, Winslow JW, Smith DH, Ramachandran J, Capon DJ (1987) Distinct primary structures, ligand-binding properties and tissue-specific expression of four human muscarinic acetylcholine receptors. EMBO J 6:3923-3929.

Perez-Reyes E, Castellano A, Kim HS, Bertrand P, Baggstrom E, Lacerda AE, Wei XY, Birnbaumer L (1992) Cloning and expression of a cardiac/brain beta subunit of the L-type calcium channel. J Biol Chem 267:1792-1797.

Porkka-Heiskanen T, Strecker RE, Thakkar M, Bjorkum AA, Greene RW, McCarley RW (1997) Adenosine: a mediator of the sleepinducing effects of prolonged wakefulness. Science 276:1265-1268.

Rahamimoff R (1968) A dual effect of calcium ions on neuromuscular facilitation. J Physiol (Lond) 195:471-480.

Reid CA, Clements JD, Bekkers JM (1997) Nonuniform distribution of $\mathrm{Ca}^{2+}$ channel subtypes on presynaptic terminals of excitatory synapses in hippocampal cultures. J Neurosci 17:2738-2745.

Reid CA, Bekkers JM, Clements JD (1998) N- and P/Q-type $\mathrm{Ca}^{2+}$ channels mediate transmitter release with a similar cooperativity at rat hippocampal autapses. J Neurosci 18:2849-2855.

Reuter H (1995) Measurements of exocytosis from single presynaptic nerve terminals reveal heterogeneous inhibition by $\mathrm{Ca}^{2+}$-channel blockers. Neuron 14:773-779.

Scanziani M, Capogna M, Gahwiler BH, Thompson SM (1992) Presynaptic inhibition of miniature excitatory synaptic currents by baclofen and adenosine in the hippocampus. Neuron 9:919-927.

Scanziani M, Salin PA, Vogt KE, Malenka RC, Nicoll RA (1997) Usedependent increases in glutamate concentration activate presynaptic metabotropic glutamate receptors. Nature 385:630-634.

Sejnowski TJ (1996) Synapses get smarter. Nature 382:759-760.

Shapiro MS, Hille B (1993) Substance P and somatostatin inhibit calcium channels in rat sympathetic neurons via different $G$ protein pathways. Neuron 10:11-20.

Shen WX, Horn JP (1996) Presynaptic muscarinic inhibition in bullfrog sympathetic ganglia. J Physiol (Lond) 491:413-421.
Simons K, Zerial M (1993) Rab proteins and the road maps for intracellular transport. Neuron 11:789-799.

Smith SJ, Zucker RS (1980) Aequorin response facilitation and intracellular calcium accumulation in molluscan neurones. J Physiol (Lond) 300:167-196.

Stanley EF (1986) Decline in calcium cooperativity as the basis of facilitation at the squid giant synapse. J Neurosci 6:782-789.

Starr TV, Prystay W, Snutch TP (1991) Primary structure of a calcium channel that is highly expressed in the rat cerebellum. Proc Natl Acad Sci USA 88:5621-5625.

Streit J, Luscher C, Luscher HR (1992) Depression of postsynaptic potentials by high-frequency stimulation in embryonic motoneurons grown in spinal cord slice cultures. J Neurophysiol 68:1793-1803.

Sudhof TC (1995) The synaptic vesicle cycle: a cascade of proteinprotein interactions. Nature 375:645-653.

Takahashi T, Momiyama A (1993) Different types of calcium channels mediate central synaptic transmission. Nature 366:156-158.

Takahashi T, Forsythe ID, Tsujimoto T, Barnes-Davies M, Onodera K (1996) Presynaptic calcium current modulation by a metabotropic glutamate receptor. Science 274:594-597.

Thevenod F, Jones SW (1992) Cadmium block of calcium current in frog sympathetic neurons. Biophys J 63:162-168.

Tomlinson WJ, Stea A, Bourinet E, Charnet P, Nargeot J, Snutch TP (1993) Functional properties of a neuronal class C L-type calcium channel. Neuropharmacology 32:1117-1126.

Tosetti P, Taglietti V, Toselli M (1999) Action-potential-like depolarizations relieve opioid inhibition of N-type $\mathrm{Ca}^{2+}$ channels in NG108-15 cells. Pflügers Arch 437:441-448.

Toth PT, Bindokas VP, Bleakman D, Colmers WF, Miller RJ (1993) Mechanism of presynaptic inhibition by neuropeptide $\mathrm{Y}$ at sympathetic nerve terminals. Nature 364:635-639.

Tsodyks MV, Markram H (1997) The neural code between neocortical pyramidal neurons depends on neurotransmitter release probability. Proc Natl Acad Sci USA 94:719-723.

Van der Loos H, Glaser EM (1972) Autapses in neocortex cerebri: synapses between a pyramidal cell's axon and its own dendrites. Brain Res 48:355-360.

Varela JA, Sen K, Gibson J, Fost J, Abbott LF, Nelson SB (1997) A quantitative description of short-term plasticity at excitatory synapses in layer $2 / 3$ of rat primary visual cortex. J Neurosci 17:7926-7940.

Wall PD (1995) Do nerve impulses penetrate terminal arborizations? A pre-presynaptic control mechanism. Trends Neurosci 18:99-103.

Wheeler DB, Randall A, Tsien RW (1994) Roles of N-type and Q-type $\mathrm{Ca}^{2+}$ channels in supporting hippocampal synaptic transmission. Science 264:107-111.

Wheeler DB, Randall A, Tsien RW (1996) Changes in action potential duration alter reliance of excitatory synaptic transmission on multiple types of $\mathrm{Ca}^{2+}$ channels in rat hippocampus. J Neurosci 16:2226-2237.

Williams ME, Brust PF, Feldman DH, Patthi S, Simerson S, Maroufi A, McCue AF, Velicelebi G, Ellis SB, Harpold MM (1992) Structure and functional expression of an omega-conotoxin-sensitive human $\mathrm{N}$-type calcium channel. Science 257:389-395.

Williams S, Serafin M, Muhlethaler M, Bernheim L (1997) Facilitation of N-type calcium current is dependent on the frequency of action potential-like depolarizations in dissociated cholinergic basal forebrain neurons of the guinea pig. J Neurosci 17:1625-1632.

Wright SN, Brodwick MS, Bittner GD (1996) Calcium currents, transmitter release and facilitation of release at voltage-clamped crayfish nerve terminals. J Physiol (Lond) 496:363-378.

Wu LG, Saggau P (1994) Adenosine inhibits evoked synaptic transmission primarily by reducing presynaptic calcium influx in area CA1 of hippocampus. Neuron 12:1139-1148.

Wu LG, Saggau P (1995) GABA $_{B}$ receptor-mediated presynaptic inhibition in guinea-pig hippocampus is caused by reduction of presynaptic $\mathrm{Ca}^{2+}$ influx. J Physiol (Lond) 485:649-657.

Wyllie DJ, Manabe T, Nicoll RA (1994) A rise in postsynaptic $\mathrm{Ca}^{2+}$ potentiates miniature excitatory postsynaptic currents and AMPA responses in hippocampal neurons. Neuron 12:127-138.

Zamponi GW, Snutch TP (1998) Decay of prepulse facilitation of N type calcium channels during $\mathrm{G}$ protein inhibition is consistent with binding of a single Gbeta subunit. Proc Natl Acad Sci USA 95:4035-4039.

Zucker RS (1989) Short-term synaptic plasticity. Annu Rev Neurosci 12:13-31. 